\section{Controls needed on release}

\section{London}

NEw legislation to back up a system of compulsory registration and licensing for any release in Britain of a genetically engineered organism is advocated in a report published last week by the Royal Commission on Environmental Pollution (RCEP). To release an organism without a licence should be a criminal offence.

The commission's long delayed but carefully considered report argues against immediately categorizing any types of release as sufficiently free of risk not to require individual scrutiny by experts and licensing by the Secretary of State for the Environment and the Health and Safety Commission (HSC). But it recommends against any moratorium on releases.

In launching the report, Lord Lewis, RCEP's chairman, said that members of the commission were persuaded that too little is known of the possible risks of releases to proceed other than in a very cautious manner. Each organism "will probably pass through several stages of experimental development and trial release", says the report, and "each stage should be the subject of a licence". A further licence would be necessary for any product containing the organism.
Pointing out that the biggest brake on the acceleration of releases, which now number about 80 worldwide, would be a case of serious damage caused by an inadequately scrutinized experiment, the commission says that "some may consider our proposals onerous but we believe them to be necessary". Should the strict controls it proposes drive people to use methods other than genetic engineering to modify organisms, particularly microorganisms, these too may have to be controlled by legislation, the report suggests.

The commission became convinced that environmental monitoring of all releases is of paramount importance, said Lord Lewis. The report says that releasers must be required not only to monitor and report their results for the agreed duration of the experiment, but to continue monitoring for "an appropriate period" thereafter, with a degree of imagination to catch any unexpected signs of damage. Compliance would be checked by appropriately trained inspectors, while Britain's army of amateur natural historians could be expected to notice any untoward effects.

Members of the commission had nothing but praise for the committee of experts that has already overseen the

\title{
Experimental releases in progress in Britain
}

\section{London}

The Royal Commission on Environmental Pollution had hoped to finish its report (see above) within a year or so but took three years. Commission member and economist Professor Aubrey Silberston said this was because the topic was unexpectedly complex and he and his fellow members were largely ignorant of it before they began. (Of the commission's 14 members, only Professor William Stewart has been an experimental biologist.) While the members were acquiring their knowledge, researchers were applying theirs to the design and execution of several release experiments.

The first release in Britain, in 1986, was a baculovirus engineered to contain an innocuous genetic marker. This initiated a series of releases aimed eventually to increase the efficiency of baculoviruses as biological control agents. The work is being carried out by Professor David Bishop and colleagues at the Natural Environment Research Council's Institute of Virology and Environmental Microbiology in Oxford with help from the Department of the Environment (DoE) and the Biotechnology Action Programme of the European Commission. In the latest release, the virus contains a bacterial 'reporter' gene in place of its coat-protein gene.

The action programme also supports risk-assessment research on plant-surface bacteria at the Oxford institute and on rhizobial bacteria at the Agricultural and Food Research Council (AFRC)'s Institute of Arable Crops Research. And DoE will this year spend a total of $£ 0.67$ million on similar research at several universities and at the Freshwater Biological Association. It hopes to double its budget next year.

A new source of finance for risk-assessment experiments is the Planned Release of Selected and Modified Organisms (PROSAMO) programme, which is half paid for by a consortium of companies and half by AFRC and the Department of Trade. A three-year $£ 1.3-$ million budget is divided between microbiological research at the Universities of Aberdeen and Essex, and plant research at AFRC's Institute for Plant Science Research and Imperial College, Silwood Park. The plant research involves the release of engineered potato plants, testing in particular the extent to which a bacterial gene engineered into potatoes can be transferred to related species by pollination.

The Royal Commission itself, with support from DOE, has supported some theoretical research to explore whether the successful HAZOP system of exposing unexpected hazards in the operation of chemical plant can be adapted to genetic engineering. GENHAZ, as it is called, has not yet been satisfactorily worked out but may be tested in a practical exercise sometime next year. handful of releases in Britain in the threeyear gestation period of the report. They recommend that this committee should be constituted in its own right to advise the Secretary of State for the Environment and the HSC on each proposed release. The committee should also produce codes of practice, advise on the need for research and the possibility of categorizing releases, and produce an annual report.

Public access to information on releases is essential, says the commission. There should be a public register of applications for experiment and product licences, and public advertisements of proposed releases. The public should also have access to the information on the basis of which the expert committee has made a recommendation, taking into account any need for commercial confidentiality.

In immediate reaction to the RCEP report, both Professor David Bishop, who has completed four UK releases of engineered baculoviruses, and UK Genetics Forum, a new group that aims to focus public concern over biotechnology, criticized the lack of public interest group representation on the expert committee proposed. The UK Genetics Forum is also disappointed that the commission did not support its call for a partial moratorium on releases, banning those with commercial aims while allowing those designed to assess risks to proceed.

Should RCEP's recommendations become the basis of new legislation, Britain would have a law largely similar to that in Denmark, the only existing European law, said commission member Lord Nathan. (The first Danish releases have just been approved - see Nature 339, 653; 29 June 1989.) The British law would, however, be considerably more restrictive than that proposed by the European Commission, and now the subject of considerable debate in the European Parliament and Council (see Nature 339, 653; 29 June 1989). RCEP's report criticizes the European proposal for its "very extensive list of exclusions" in respect of the products that would require control and for its 'single market' proposals that a product approved in one European Community country should not be restricted in others. This, the report argues, ignores the very different geographical environments in Europe.

RCEP's recommendations fall within the possibilities for new legislation very recently put forward in a Department of the Environment consultation paper (see Nature 339, 499; 15 June 1989) but are at the stricter end of the spectrum. The department will be considering reactions to both documents after the summer and hopes to finalize new legislation to control the release of genetically engineered organisms in time to include it in a general environment bill that may be ready later this year.

Peter Newmark 